\title{
RĀMA: HELT, GUD OG POLITISK SYMBOL
}

\author{
Rasmus Reinvang
}

\begin{abstract}
1. Indledning ${ }^{1}$
Historien om Prins Rāma, Rāmāyana, har i mere end to tusinde år stået centralt i den indiske kultursfære. Rāma-skikkelsens udvikling er et godt eksempel på den kontinuitet, som er karakteristisk for hinduistisk kultur, hvori skrifter, trosforestillinger og ritualer er blevet bevaret, opretholdt og udført igennem en historie med skiftende statsdannelser, invasioner og udefra kommende religioner som zoroastrisme, islam og kristendom. Dyrkelsen af Rāma er dog lige så lidt som den mere overordnede størrelse 'hinduisme'2 en bastant og entydig størrelse, der er blevet båret upåvirket op gennem historien. Rāmāyana tager form i løbet af de sidste århundreder før vor tid i Nordindien, spredes i løbet af det næste årtusinde til alle egne af den indiske kultursfære (dvs. det indiske subkontinent såvel som dagens Burma, Thailand, Cambodja, Indonesien og Malaysia), og tager utallige lokale former afhængig af de særlige kulturelle og geografiske forhold, som gør sig gældende forskellige steder.

Det er i en enkelt artikel kun i begrænset omfang muligt at gøre rede for de forskellige positioner, Rāmāyana har indtaget op gennem historien. Den umiddelbare baggrund for denne artikel er en analyse af den centrale stilling, Rāma-skikkelsen indtager i den politiske udgave af en moderne hindunationalistisk ideologi i dagens Indien. Til trods for at den hindunationalistiske bevægelses tolkning af Rāmāyana i bund og grund er determineret af forhold, der er uløselig knyttet til nutidens politiske situation i staten Indien, som igen $\mathrm{i}$ en meget stor grad er funderet på den britiske definition af det mo-
\end{abstract}

\footnotetext{
${ }^{1}$ Artiklen er en revideret udgave af et foredrag holdt under et seminar med titlen "De udødelige vers, et seminar om epos i verdenslitteraturen”, d. 19.-20. marts 1999 på Københavns Universitet.

${ }^{2}$ Forestillingen om en religion ved navn 'hinduisme' (eller for den sags skyld en kultur der er 'hinduistisk'), som udgør en homogen størrelse, der foreligger i forskellige former gennem historien, er et resultat af den vestlige verdens forsøg på at klassificere og definere alt det, man fandt i Indien, som man ikke kunne tilbageføre til kendte størrelser som f.eks. islam. Ordet 'hindu' er afledet af persisk, og forud for briterne var der ingen bevidsthed blandt Indiens ikke-muslimske folk om, at de udgjorde en kulturelt homogen enhed, der stod samlet i modsætning til muslimer og kristne. Som forestilling og identitetsmarkør ankommer 'hinduismen' altså til Indien med briterne. Det er derfor problematisk, når man snakker om hinduisme før briternes ankomst, idet vi dermed projicerer en forestilling om en bevidst overordnet kulturel identitet over på de folk, vi omtaler, som ville have været fremmed for dem selv. Jeg bruger i artiklen enkelte gange ordet 'hinduistisk' i anførselstegn, når jeg føler, at termen er problematisk og ønsker, at læseren skal være sig betegnelsens kunstige karakter bevidst ud fra et historisk perspektiv. Ordet 'hinduisme' er på den anden side en praktisk betegnelse for en mangeartet indisk kultur, der kan identificeres historisk, og som har visse grundlæggende parametre, der adskiller den fra f.eks. den muslimske kultur, og det er som et sådant løst begreb, ordet bruges i artiklen, så længe det forekommer uden anførselstegn.
} 
derne Indien, repræsenterer den hindunationalistiske bevægelses tolkning af Rāmāyana samtidig en forlængelse af den måde, hvormed den hinduistiske tradition på utallige måder bærer sine centrale symboler med sig gennem historien. For at illustrere dette og udstille forskellige positioner, Rāma har indtaget i indisk kulturhistorie, leder artiklen op til fremstillingen af dagens brug af Rāma ved først at beskrive, hvordan Rāma oprindeligt blev fremstillet som et ikon, der afspejlede krigerklassens (ksatrīyavarna) etos og senere i Gupta-perioden (320-500 e.v.t.) blev omfortolket til at repræsentere guds tilstedeværelse og kamp mod det onde på jorden. Artiklens redegørelse for den moderne hindunationalistiske bevægelses brug af historien om Rāma er på sin side en beskrivelse af centrale elementer i den hindunationalistiske etos, og hvordan disse er blevet produceret og gjort til kulturel virkelighed for stadig flere i løbet af de sidste tyve år. Den politiske brug af Rāma-skikkelsen har været stærkt medvirkende til, at det hindunationalistiske Bharatìya Janata Party (BJP) - "Det Indiske Folkeparti" - siden 1996 har været Indiens største parti og i dag er i regeringsposition. Som antydet i overskriftens henvisning til Rāma som hero, gud og politisk symbol, beskriver artiklen således tre karakteristiske faser i forståelsen af Rāma-skikkelsen i de sidste rundt regnet 2300 år.

\section{Rāmāyana}

Eposet Rāmāyana fandt sin klassiske form i begyndelsen af Gupta-perioden (320-500 e.v.t.), ${ }^{3}$ men kernen i historien stammer sandsynligvis fra perioden mellem år $500 \mathrm{og}$ 200 før vor tidsregning. Rāmāyana har, ligesom det andet og langt større klassiske indiske epos Mahābhärata, sit historiske udgangspunkt i de gamle skjaldes lovprisninger af og fortællinger om samtidige og fordums tiders helte og begivenheder ved den lokale konges hof. Det er almindeligt anerkendt i den religionshistoriske forskning, at Rāmāyanas første og sidste bog må være senere tillæg til de centrale bøger 2-6. Bøgerne 2-6 kan således siges at indeholde Rāmāyanas oprindelige episke grundhistorie. Kontrasten mellem fremstillingen af Rāma i kernebøgerne 2-6 og Rāma-skikkelsen, som den fremstår i den senere ramme, der udgøres af bøgerne 1 og 7, vil klargøres i det følgende. Fremstillingen af den klassiske Rāma bygger i bund og grund på Brockingtons (1984) klassisk-filologiske studie Righteous Rāma, der betragtes som det autoritative studie af Rāmāyana i den nyere religionshistoriske forskning. Ethvert historisk-kritisk studie af klassisk anonym sanskritlitteratur er problematisk, og de historiske forklaringsmodeller, forskeren udarbejder, er af natur hypoteser, der nuanceres, videreudvikles eller forkastes med tiden. Fosse (1997) har i den senere tid kommenteret Brockingtons historiskkritiske tolkninger af Rāmāyana og den problematiske karakter, som præger den anonyme sanskritlitteratur, på baggrund af en studie, hvor han har kørt udvalgte passager af

\footnotetext{
${ }^{3}$ Perioden betegnes ofte som det klassiske Indiens 'guldalder', på grund af den kulturelle opblomstring, der fandt sted under Gupta-styret.
} 
Rāmāyana og andre klassiske tekster gennem et computerprogram, der opstiller statistiske analyser af grammatiske kriterier ud fra hvilke, det er muligt at få et indtryk af de grammatiske mønstre, der gør sig gældende i forskellige tekster og i forskellige lag af den samme tekst. Til trods for at Brockingtons studie i dag er det bedste bud, vi har på en overordnet historisk-kritisk tolkning af den klassiske tekst, så illustrerer Fosses studie, at nye metodologiske indfaldsvinkler til materialet er mulige, at vores forståelse af det pågældende materiale dermed må udvikle sig i takt med vores erkendelsesmuligheder, og at forståelse som sådan aldrig er endelig. ${ }^{4}$ Spørgsmålet om hvordan vi med en vis sikkerhed kan skelne mellem de forskellige historiske tekstniveauer, der foreligger i den klassiske Rāmāyana, er ikke endelig afklaret og bliver det måske aldrig. Denne problematik synes dog ikke at påvirke artiklens alment accepterede grundtese, at Rāmaskikkelsen oprindeligt fremstod som en menneskelig hero, der af senere redaktører blev gjort til en inkarnation af Visnu, for igen i moderne tid at indtage en ny rolle som et maskulint symbol på hindunationalistisk selvhævdelse.

\section{Fortællingen om Rāma}

Den episke grundhistorie er i korte træk som følger: Kong Daśaratha er hersker i riget Kośala i Nordindien. Daśaratha er i sit livs efterår og begynder forberedelserne til at gøre sin ældste søn, den ædle og i alle henseender perfekte Rāma, til tronarving. Men kongens hustru nummer to, Kaikeyī, kræver, at hendes søn skal udnævnes til tronarving i stedet. Kaikeyī minder kongen om, at han i sin ungdom lovede at opfylde et af hendes ønsker som tak for, at hun reddede hans liv en gang, hovedstaden Ayodhyā blev forsøgt stormet af fjender. Kaikeȳ̄ kræver nu sin ret og forlanger, at Rāma skal sendes i eksil i

\footnotetext{
${ }^{4}$ Fosse (1997, 213-216) har i sin doktorafhandling The Crux of Chronology in Sanskrit Literature undersøgt passager fra de i alt fem historiske niveauer, som Brockington definerer i Righteous Rāma (passager der vel og mærke er udvalgt af Brockington selv), og analyseret dem ved hjælp af computerbaserede statistiske metoder med henblik på at identificere historiske niveauer på basis af lingvistiske kriterier. Fosse bemærker, at den udførte computeranalyse af et begrænset antal tekststykker fra Rāmāyana ikke fremviser nogle "lingvistiske beviser" for Brockingtons fem historiske niveauer, og at undersøgelsen antyder, at "the development of the Rāmāyana so far assumed by scholarship might need to be revised" (ibid., 214). Fosse bemærker, at Rāmāyana meget vel kan have været overleveret i forskellige versioner mere eller mindre fra begyndelsen. Dele, som i den nuværende udgave virker som sene tillæg, kan derfor stamme fra en oprindelig alternativ version. Denne version kan så være blevet lagt til vores nuværende recension på et forholdsvis sent tidspunkt, i en grammatisk form der afspejler inkorporeringstidspunktet, men ikke nødvendigvis tekstindholdets alder. Når det gælder problematikken omkring dateringen af anonym sanskrit-litteratur, bemærker Fosse (ibid., 216) forøvrigt: "texts were continually subject to contradictory processes that sometimes produced better, sometimes worse Sanskrit than what was attested in the older versions of the text. Like all languages, Sanskrit was a dynamic system that underwent fluctuations of various kinds, but unlike natural languages that usually develop in one main direction, Sanskrit as a classical literary language was able to draw on several registers both diachronically and diastratically at once, thus creating much more confusion than we would ordinarily expect."
} 
vildmarken i fjorten år, og at hendes søn, Bharata, indsættes som tronarving. Den gamle konge er fortvivlet. Han må holde ord, for hvis man ikke kan stole på en konges ord, hvad kan man så regne med? Hvis ikke engang kongen gør sin pligt, opretholder dhar$m a$, hvad forhindrer så verden i at synke ned i kaos? Men Rāma er den perfekte søn og arving, han er elsket og set op til af alle og som skabt til at herske længe og retfærdigt. Hvordan kan det være dharma, at prins Rāma skal drives ud i et fattigt liv i vildmarken og berøves sin fædrene ret? Og hvordan skal Daśaratha kunne udholde at bortvise og skilles fra sin elskede, ældste søn i fjorten år? Hvordan kan det være dharma? ${ }^{5}$ Daśaratha er forvirret og fortvivlet. Selv ikke den ny arving, Bharata, synes Kaikeyīs påfund er en god idé. Kaikeyī fastholder dog sit krav, og Rāma insisterer uselvisk på, at kongen må holde ord, og drager frivilligt i eksil sammen med sin kone, Sītā, og den trofaste halvbror Laksmana. Daśaratha kan ikke komme sig over, hvad der er sket, og over at have mistet sin søn for de næste mange år. Han visner hen og dør snart af sorg. Bharata overtager dernæst modvilligt styret af kongeriget, indtil Rāma en skønne dag vil vende tilbage fra vildmarken. For at ingen skal tro, at han har nogen del i komplottet mod Rāma, nægter Bharata at sætte sig på tronen og placerer Rāmas sandaler på den i stedet!

Rāma, Sītā og Laksmana lever i mange år et simpelt liv ude i skoven. Rāma forsvarer, som den ædle kriger han er, skovens asketer, eneboere og landsbyfolk mod vildmarkens dæmoner ( $r a \bar{k} s a s a)$ og andre farer. Men en dag bliver den fæle rāksasī Súrpanakhā forelsket i Rāma! Hendes tilnærmelser afvises med afsky, hvorefter hun forsmået og jaloux angriber Sītā med det ene resultat, at Laksmana griber ind og slår hende til krøbling. Sūrpanakhās bror, Khara, pudser nu fjorten mægtige dæmoner på brødrene, der dræber dem alle. Khara vender derefter tilbage med en hær på 14.000. Rāma dræber dem alle alene. Den forsmåede Śūrpanakhā henvender sig nu til sin mægtige bror, Rāvana. Suurpanakhā, der kender kvindesindets svagheder, instruerer ham i en plan med det formål at bortføre Sītā: Rāvana tvinger en af sine undersåtter til at tage form af en gylden hjort. Straks Sītā får øje på den gyldne hjort, sender hun Rāma ud for at nedlægge den til hende. Men der er trolddom med i spillet, og den ellers så suveræne jæger Rāma bliver gradvist lokket længere og længere væk fra Sītā. Rāvana kopierer dernæst Rāmas stemme, og pludselig lyder der råb om hjælp inde fra skoven. Sītā skynder på Laksmana, for at han skal komme Rāma til undsætning, men Laksmana nægter, da han har lovet Rāma ikke at forlade Sītā. Sītā beordrer så Laksmana at komme Rāma

\footnotetext{
${ }^{5}$ Dharma er den handling, der opretholder den vediske kulturverden, der som en meningsfyldt og lovmæssig orden står i modsætning til den rå eksistens' meningsløshed og vilkårlighed. Verdensordenen, der afspejles i kosmos' lovmæssighed såvel som af det vediske samfunds struktur, må konstant opretholdes over for kaoskræfterne, og derfor indebærer dharma kontinuerlig handling og virkeliggørelse af den vediske kulturverden $\mathrm{i}$ henhold til ens position i det vediske samfund: "It [dharma] is the continuous maintaining of the social and cosmic order and norm which is achieved by the Aryan through the performance of his Vedic rites and traditional duties." (Halbfass 1990, 315-316).
} 
til hjælp, hvorefter han modvilligt forsvinder ind i skoven. Den dæmoniske plan er hermed lykkedes; Sītā er ladt alene. Rāvana træder nu frem og bortfører Sītā til La_ka, hvor hun efter at have afvist alle Rāvanas tilnærmelser holdes i forvaring i en lille lund.

Rāma og Laksmana indgår i det efterfølgende en alliance med skovkongen Sugrīva for at stå stærkere i eftersøgningen og den formodede redning af Sītā. Efter at have hjulpet Sugrīva med at vinde sin trone tilbage fra sin bror og efter rastløst at have set en regntidsperiode passere, hvori al eftersøgning er umulig, sendes der ekspeditioner med Sugrīvas abesoldater ud i alle retninger for at finde Sītā. Alle hold vender tilbage undtagen det, der ledes af Sugrīvas abegeneral Hanumān, og Rāma er i flere omgange på selvmordets rand på grund af sin bekymring for og længsel efter sin elskede. Hanumān får nu på sin mission at høre, at Sītā befinder sig på øen Lanka, og udfører et fantastisk spring over vandet ud til øen, hvor han giver sig til kende for Sītā. Sītā nægter dog at flygte med Hanumān, idet hun finder det naturligt at skulle reddes af Rāma selv. Hanumān hærger derefter Lanka, dræber flere mægtige dæmoner og lader sig til sidst fange for at få Rāvana at se. Den rasende Rāvana sætter ild til Hanumāns hale for således at give ham en lærestreg, men planen slår fejl, da Hanumān stikker af og bruger sin brændende hale som en fakkel, hvormed han sætter ild til hele øen. Derefter tager Hanumān tilbage for at fortælle Rāma nyhederne om Sītā. Rāma sætter så ud mod La_ka med en hel hær, og i det endelige slag vinder Rāma til sidst tvekampen mod Rāvana efter at have fået stillet selveste den vediske gudekonge Indras kampvogn og kusk til rådighed.

Sandsynligvis sluttede historien oprindeligt med Rāma og Sītās genforening og triumferende tilbagetog til Ayodhyā (idet de fjorten år nu er passeret), men som afslutningen nu foreligger i bog 6 , er det hele blevet mere kompliceret. Historien får her en drejning, der afspejler centrale hinduistiske forestillinger om renhed og moral. Sītā havde som en ærbar kvinde holdt stand mod Rāvanas tilnærmelser, men hendes dyd var alligevel krænket og hendes renhed skændet. Det er sandsynligvis i lys af en senere tids moralske anfægtelser, at Rāma nu her (for første gang) siger, at han har reddet hende og straffet Rāvana af hensyn til familiens ære og ikke på grund af hende alene. Sītā vælger nu den eneste ærbare og endegyldige løsning; hun træder roligt ind i et frådende bål og lader sig omslutte af flammerne. Guderne viser sig dernæst for Rāma og afslører, at han faktisk er en inkarnation af Visnu, hvorefter ildguden Agni giver en lutret Sītā tilbage til sin henrykte mand. Rāma og Sītā vender derefter hjem til Ayodhyā, hvor Rāma hersker retfærdigt i ti tusinde år.

Således er Rāmāyanas grundhistorie, der fandt sin form omkring vor tidsregnings begyndelse. Vi finder i den ældre buddhistiske pāli-kanon en jātaka-historie, hvor den ædle prins Rāma og hans uretfærdige udstødelse beskrives, men hvor intet nævnes om bortrøvelsen af Sītā og det følgende opgør med dæmonkongen Rāvana. Dette antyder, at grundhistorien i Vālmīkis Rāmāyana integrerer i hvert fald to oprindeligt uafhængige fortællinger: historien om den ædle prins og tronarving, der bliver drevet i eksil, og historien om øen Lankas erobring. 


\section{Rāma som krigerklassens hero}

Rāma fremstår i grundhistorien som en helt, en idealiseret skikkelse, men ikke som guddommelig. Det er derfor også en overraskelse for Rāma selv, når vi i slutningen af bog 6 pludselig hører, at han er en inkarnation af Visnu! Rāma er i udgangspunktet det idealiserede medlem af hersker og krigerklassen (ksatrīyavarna). Rāmāyanas klimaks er således naturligt nok Rāmas endelige opgør med Rāvana på slagmarken. Rāma legemliggør en ksatrīyas dyder, når han i skoven beskytter folket og skovens hellige mænd mod de onde dæmoner. Rāmas idealiserede karakter illustreres af hans uselviske og pletfri opførsel. Når hans fortvivlede far skyldbetynget fortæller ham, at han må flytte ud i vildnisset i fjorten år og ikke kan blive konge, bliver Rāma ikke vred eller skuffet, men accepterer roligt sin faders vilje. Ikke bare repræsenterer Rāma den lydige søn, han argumenterer endda for, at faren må holde sit ord til trods for, at det har fatale følger for ham selv. Rāma fremstår således også som en uselvisk opretholder af dharma. At opretholdelsen af dharma for Rāma går forud for enhver personlig interesse eller præference, understreges af grundhistoriens slutfase, hvor Rāma efter endelig at være blevet genforenet med sin elskede Sītā køligt afviser hende, idet hun må betragtes som uren. Heldigvis borger Agni for Sītās renhed, hvorefter Rāma kan tage hende tilbage uden at bryde dharma. I lys af Rāmas noble karakter er det ikke mærkeligt, at han i Rāmāyanas grundfortælling generelt sammenlignes med Indra, der foruden at være gudernes konge også er en stor kriger og således repræsenterer de samme ksatrīya-dyder som Rāma. Rāmas halvbror, Laksmana, sammenlignes til gengæld ofte med Indras hjælper Visnu, sådan som forholdet beskrives i vedaerne.

Den retfærdige Rāma repræsenterer også den ideelle ægtemand, på samme måde som Sìtā-skikkelsen legemliggør idealet om den trofaste og hengivne hustru. Prinsesse Sìtā, der altid var blevet serveret den fineste mad, iklædt det fineste tøj og hele sit liv havde levet ved hoffet, er således ikke et øjeblik i tvivl om, at hun vil følge sin mand på hans fattige eksil i vildmarken. Rāma er ligeså hengiven over for sin hustru, som hun er over for ham. I de utallige versioner af Rāmāyana, mundtlige såvel som skriftlige, der har vandret over Indien de sidste to tusinde år, er der få temaer, der er blevet udfoldet $i$ samme grad som Rāma og Sîtās hengivenhed over for hinanden. Fortællerne giver tilsyneladende aldrig op i deres forsøg på fyldestgørende at beskrive den påtvungne adskillelses effekt på det elskende par. Vi hører således i alenlange beskrivelser om Sîtās stolte opretholdelse af sin værdighed og ære under fangenskabet hos Rāvana, om hendes ensomme fortvivlelse over tabet af sin elskede, hendes bekymring for om han stadig lever, om hun nogensinde vil se ham igen, og om de nogensinde vil genforenes. På samme måde udfoldes Rāmas sorg og bekymring over bortrøvelsen af sin kone, en bekymring der, gentagne gange under den flere måneder lange eftersøgning af Sītā, overmander ham og hensætter ham $i$ en nærmest apatisk tilstand af bundløs fortvivlelse og til tider bringer ham på selvmordets rand. Dette er selvfølgelig meget romantisk, men må også ses som et udtryk for en idealiseret fremstilling af Rāmas opretholdelse af ægteskabets dharma i form af kærlighed, hengivenhed, trofasthed og omsorg. 


\section{Rāma som inkarnation af den almægtige Visnu}

I løbet af de første århundreder efter vor tidsregnings begyndelse blev Rāmāyanas grundfortælling udvidet med en ramme, der udgør bog 1 og 7 i den klassiske tekst og som ligger til grund for nutidens mange versioner. I denne redaktionelle fase blev grundfortællingen genstand for redigeringer af både śaivistiske og vaisnavistiske brahmaner. I sin klassiske form ${ }^{6}$ er Rāmāyana et resultat af en vaisnavistisk redigering, men der er stadig spor af, at historien tidligere har set śaivistiske redigeringer. Den vaisnavistiske redigering har to overordnede konsekvenser for den klassiske tekst. For det første indordnes Rāma-skikkelsen i den vaisnavistiske avatāra-lære, ${ }^{7}$ og for det andet tilpasses en tradition, der oprindelig reflekterede en ksatrīya-etos, nu brahmanklassens langt mere stivbenede forestillinger om renhed og urenhed. Begge faktorer er fremtrædende i Rāmāyanas første og sidste bog. Den første bog fortæller om Rāmas ungdom, hvordan han vandt Sītās hånd, og hvordan Rāma og til en vis grad også hans halvbrødre er inkarnationer af Visnu. Det er således nu klart fra starten af eposet, at Rāma er en inkarnation af Visnu, noget hele den efterfølgende historie må ses i lyset af. Śiva sættes i begyndelsen på plads, idet der fortælles, hvordan Rāma ved et offerritual hos kong Janaka griber Śivas bue, som ingen mand har styrke nok til at kunne strenge. Rāma strenger den og spænder den, til den knækker. Janaka er forøvrigt Sītās far og besøget ender med, at Rāma ægter Sītā. Hvor Rāma i bog 2 til 6 af Rāmāyana gennemgående sammenlignes med krigerguden Indra og Laksmana med Indras hjælper Visnu, så regnes Rāma i de senere bøger 1 og 7 for at være en inkarnation af den nu almægtige Visnu.

I den sidste bog udlægges dæmonkongen Rāvanas forhistorie, og vi får at vide, at han var en modstander af guderne, der gennem ekstrem askese fik guden Brahmā til at fremtræde og tilstå ham opfyldelsen af et ønske. Rāvana ønskede, at han måtte blive usårlig for alle væsener, der står højere end mennesket, for således trygt at kunne bekæmpe guderne. Med dette får vi den teologiske forklaring på Visnus inkarnation som Rāma: Visnu inkarneres som mennesket Rāma for i menneskeform at kunne få has på den for guderne usårlige Rāvana. Rāmas overvindelse af Rāvana bliver i tråd med

\footnotetext{
${ }^{6}$ Den klassiske form af eposet, som der her henvises til, er en grundform, der må anses for at ligge bag de mange nyere manuskripter, vi i dag kender. Overordnet kan man ud fra det samlede materiale klart se, at en klassisk vaisnavistisk version, der fandt sin form i løbet af Gupta-perioden, ligger til grund for dagens kilder.

${ }^{7}$ Ifølge avatāra-læren inkarnerer den almægtige Visnu sig på forskellige tidspunkter på jorden i en eller anden form for at hjælpe menneskene. Antallet af inkarnationer varierer i de ældste purāna-tekster, men traditionen omtaler efterhånden konsekvent ti. De er fisken, skildpadden, ornen, menneske-løven, dværgen, Paraśurāma, Rāma, Krsna, Buddha og Kalki (som kommer på dommedag). Rent religionshistorisk er det klart, at dette system indordnede en række oprindeligt forskellige kulter under en overordnet vaisnavistisk teisme.
} 
dette sat ind i et større perspektiv. Rāmas sejr sidestilles nu med gamle vediske legender om sejre med kosmisk betydning, bl.a. fortællingen om, hvordan den vediske Visnu vinder hele universet tilbage fra dæmonen Bali (Rgveda 1.154). Rāmāyana får også en ny slutning, åbenbart fordi brahmanklassen følte, det var problematisk, at Rāma tog Sìtā tilbage, selvom Agni sagde god for hendes renhed. Med Rāma som guddommelig inkarnation er det tydeligt, at de vaisnavistiske brahmaner ikke kunne acceptere den mindste tvivl om Rāmas integritet og evne til kompromisløs skelnen mellem rent og urent. I den nye slutning i bog 7 fortælles det således, at folket i Rāmas kongerige var utilfredse, og at mistankerne om Sītās urenhed ikke blev fjernet, selv om Agni beviste hendes renhed ved ikke at ville fortære hende. Rāma, hvis pligt som konge var at tjene sit folk, måtte derfor modvilligt udstøde hende. Sītā slog sig dernæst ned i Vālmīkis eneboerhytte i vildmarken, hvor hun fødte Rāma tvillinger. Mange år senere mødte Rāma Sītā igen og anerkendte sønnerne. ${ }^{8}$ Som et endeligt bevis på sin renhed påkaldte Sītā moder jord og bad den sluge hende, såfremt hendes renhed og ære i sandhed var uplettet. Jorden slugte hende, og Rāma måtte leve endnu mange år uden sin Sītā, før han endelig vendte tilbage til himlen og antog sin egentlige form som Visnu.

Denne slutning føjer en ny dimension til historien uden at forandre det faktum, at Sītā til syvende og sidst anerkendes som uplettet. Den væsentlige forskel er, at Rāma og Sìtā aldrig får hinanden. Det er tydeligt, at den brahmanske fiksering på renhed og urenhed ikke kunne hæve sig over det faktum, at Sītā trods alt har brudt sit ægteskabsløfte, idet hun har boet under en anden mands tag, og at denne holdning har dikteret den nok for de fleste mere utilfredsstillende slutning. Den nye slutning bliver da også ofte omskrevet eller modificeret i de mange forskellige versioner af Rāmāyana, der er opstået siden den sidste redaktion af den klassiske tekst. Rāmāyanas store popularitet særligt i Nordindien indtil denne dag illustreres ved, at historien stadig fremføres under den årlige Daśahrā-festival, hvor man som regel slutter i den mere oprindelige versions ånd. Det gør man ved en opførelse af Rāma og Sītās triumferende genkomst til Ayodhyā i den lokale hovedgade.

\section{Rāma som hindunationalistisk symbol}

I kontrast til og i forlængelse af den episke og religiøse fremstilling af Rāma beskrevet i det foregående, er Rāma-skikkelsen i nutidens Indien blevet indskrevet i en politisk kontekst af den hindunationalistiske bevægelse. Den hindunationalistiske bevægelses

\footnotetext{
${ }^{8}$ Vālmīki er den legendariske forfatter af Rāmāyana. I de sene bøger 1 og 7 fortælles det, at Vālmīki blev rørt til at udtrykke sine følelser i digt efter at have overværet en trane blive skudt af en jæger. Efter at den første inspiration havde fortaget sig, hentede Vālmīki resten af historien frem i dyb meditation. De første, der lærte Rāmāyana at kende fra Vālmīki, var Rāmas sønner, Kuśa og Lava, der voksede op i Vālmīkis āśrama. Kuśa og Lava stod senere for den første offentlige fremførelse af Rāmāyana for Rāma og hans hof under afholdelsen af det vediske hesteoffer. Det er her, Rāma anerkender sine sønner og sender bud efter Sītā.
} 
rygrad udgøres af den militante organisation Rashtriya Swayamsevak Sangh (RSS), der blev stiftet i 1925 og har været forbudt i to korte perioder. Første gang var umiddelbart efter drabet på Gandhi i 1948. Mordet blev udført af et tidligere medlem af RSS, men da undersøgelseskommissionen ikke kunne finde noget bevis på, at RSS var involveret i mordet, blev RSS tilladt igen efter en kort periode. RSS var også forbudt en kort periode i begyndelsen af halvfemserne på grund af sin rolle i konflikten omkring Babri-moskéen i Ayodhya (der omtales udførligt i det følgende). Ved siden af RSS er den hindunationalistiske bevægelse organiseret gennem kulturorganisationen Vishva Hindu Parishad (VHP), der ligeledes har været forbudt siden begyndelsen af halvfemserne på grund af sin aktive rolle i konflikten omkring Babri-moskéen. Den hindunationalistiske bevægelse er desuden organiseret politisk gennem partiet BJP, der siden parlamentsvalget i 1996 har været Indiens største parti, og som de sidste år har stået i spidsen for en koalitionsregering. Også BJP var forbudt i en kort periode i begyndelsen af halvfemserne på grund af dets rolle i konflikten omkring Babri-moskéen.

Den hindunationalistiske bevægelse anklager den indiske stat for at være "pseudosekulær", idet den efter bevægelsens mening ikke respekterer hinduernes rettigheder i relation til deres numeriske flertal. Den hindunationalistiske bevægelses store fremgang de sidste femten år skyldes flere forhold. Der har som følge af en stadig mere udbredt korruption og mangel på visioner været stor utilfredshed med Kongrespartiet (det parti der har domineret indisk politik siden uafhængigheden). Den stadig stærkere politiske mobilisering af de lavere kaster spiller også ind. Den har i de senere år genereret et betydeligt pres på offentlige stillinger og uddannelsesfaciliteter og skabt udbredt frygt og frustration blandt de højere kaster i specielt Nordindien og i de hastigt voksende middelklasser overalt i Indien. Den hindunationalistiske bevægelse vil gerne genoprette det, den opfatter som en oprindelig og harmonisk hinduisme, og på den baggrund kræver den, at der må rådes bod på den historiske uret begået mod hindukulturen af fortidens muslimske fyrster, og at staten og den (venstreorienterede) politiske elite må tillade almindelige mennesker at være hinduer til fulde uden dermed at beskylde dem for at være antimuslimske eller usolidariske med de lavere kaster.

Konflikten omkring Babri-moskéen i Ayodhya er den konkrete enkeltsag, der har haft størst symbolværdi for den moderne hindunationalistiske bevægelse, og det er i denne sammenhæng, at historien om Rāma bliver trukket ind i en politisk kontekst. Babri-moskéen i Ayodhya blev rejst i 1528. Ifølge den hindunationalistiske bevægelse er moskéen rejst på ruinerne af et oprindeligt hindutempel, der markerede Rāmas fødested. Vi har i dag ingen historiske kilder, der kan bekræfte dette, og forestillingen om det oprindelige Rāma-tempel kan ikke spores længere tilbage end til sidste halvdel af 1700-tallet. I 1982 påbegyndtes en kampagne for befrielsen af "Rāmas fødested" (Ramjanma-bhomi). Kampagnen blev langsomt bygget op i delstaten Uttar Pradesh, med årlige marcher til Ayodhya og en stadig større organisering af lokale hellige mænd og tempelbrahmaner inden for kulturorganisationen VHP. Ayodhya og Rāma-dyrkelsen blev dermed centrum i en bredt anlagt politisk og religiøs kampagne, der satte ligheds- 
tegn mellem det geografiske Indien og et organiseret hindufællesskab. Et godt eksempel på denne brede kampagnes karakter er en specifik kampagne, der fandt sted i 1989. Under denne kampagne transporterede hindunationalistiske aktivister hundredetusindevis af mursten ud til landsbyer og boligområder i hele Uttar Pradesh, fik en lokal brahman eller en ældste til at indvi og velsigne stenen, for derefter at fragte stenene tilbage til det rituelle centrum i Ayodhya for at indgå i konstruktionen af et nyt Rāma-tempel. I denne kampagne konstrueredes således et konkret geografisk hindufællesskab med Ayodhya og Rāma som henholdsvis det myto-historiske og religiøse centrum.

Etableringen af Rāma-skikkelsen som et nationalt symbol for den mangeartede hindukultur blev fra 1988 hjulpet godt på vej af lange tv-filmatiseringer af Rāmāyana og Mahābhārata, der tømte gaderne, hver gang der blev vist en episode over den nationale tv-kanal. I 1990 kastede BJP sig ud i den stadig mere oppiskede stemning omkring Ayodhya. Partiets leder Advani drog ud på en stort anlagt rejse fra Somnath-templet ${ }^{9} \mathrm{i}$ det nordvestlige Gujarat til Ayodhya i en Toyota-varevogn, der var dekoreret præcis ligesom Rāmas stridsvogn i tv-serien. Rejsen, der blev fremstillet som en traditionel pilgrimsrejse (yatra), var nøje planlagt og iscenesat ved hjælp af tusindvis af hindunationalistiske aktivister. Undervejs hyldede man Advani som en inkarnation af Rāma, unge mænd overrakte ham skåle med aftappet menneskeblod og optrådte med sværd og trefork (såkaldte "rituelle våben" der er knyttede til de indiske guder), og musikken fra tvserien blev afspillet under nøje planlagte massemøder. Samtidig sørgede bevægelsen for at fodre journalisterne i storbyerne med rapporter og billedmateriale fra den tilsyneladende spontane, men i virkeligheden nøje orkestrerede dyrkelse af Advani som Rāma i det nordlige Indiens mange små landsbyer. Under den afsluttende fase af kampagnen var der i Ayodhya sammenstød mellem hindunationalistiske aktivister og paramilitære styrker, der var sat ind af centralregeringen for at beskytte Babri-moskéen. I disse sammenstød blev mere end 30 aktivister dræbt. Deres urner blev i de næste måneder transporteret rundt i landet som relikvier, og de afdøde blev dyrket som religiøse martyrer og helgener. Gennem en omfattende forfalskning og distribuering af billedmateriale, der angiveligt skulle være dokumentation af den sekulære stats grusomhed over for hinduerne, opbyggede den hindunationalistiske bevægelse efterfølgende en folkelig myte om begivenhederne i Ayodhya som en systematisk massakre af tusindvis af såkaldte "tempelfrivillige" (kar sevaks). I 1992 blev Babri-moskéen stormet af hindunationalistiske aktivister og ødelagt. Grunden er i dag indhegnet og bevogtet af sikkerhedsstyrker,

\footnotetext{
${ }^{9}$ Det er her af stor symbolsk betydning, at Somnath-templet er en rekonstruktion af det berømte Somanāthatempel, der blev plyndret og raseret af muslimske styrker fra Afghanistan i begyndelsen af det 11. århundrede. De persiske krøniker fortæller, hvordan titusindvis af lokale indbyggere og andre tilknyttet templet blev massakreret $\mathrm{i}$ forsøget på at forsvare deres guddom og den enorme guldbeholdning, der blev opbevaret $\mathrm{i}$ templet. Krønikerne hylder desuden hærføreren Mahmud af Ghazni som de indiske vantros besejrer, og Mahmud fremstår derfor for hindunationalisterne som selve arketypen på den hindu-undertrykkende muslimske fyrste.
} 
mens det moderne indiske samfund prøver at komme til enighed om, hvad der skal gøres med den.

Den moderne hindunationalistiske selvhævdelse i særlig nordindiske højkastemiljøer og i den voksende indiske middelklasse, er i udgangspunktet en følge af politiske forhold. Den traditionelle brahminske elite oplever sin sociale og politiske førerposition som truet af det muslimske mindretal og af de enorme grupper af lavere kasters stadig større indflydelse og selvbevidste deltagelse i den indiske offentlighed. Den hindunationalistiske bevægelse er i udgangspunktet en reaktion på, at den sekulære indiske stat har været forholdsvis succesfuld med at demokratisere det indiske samfund. Den traditionelle hinduelite står til at tabe privilegier, noget den og dens sympatisører ikke vil tillade uden kamp. I denne politiske konflikt mellem forskellige grupper i det indiske samfund, hvoraf hindunationalisterne og deres sympatisører udgør et mindretal, gøres der brug af religiøse symboler, og det er i denne sammenhæng Rāma-skikkelsen omdefineres. Den traditionelle ikonografiske afbildning af Rāma viser enten et blidt barn eller en klog og moderat hersker, men i den maskuline hindunationalistiske fremstilling fremstår han med bar og muskuløs brystkasse, bevæbnet og klar til kamp som en slags "Rām-bo". Modsætningen mellem den onde Rāvana og Rāma læses i de hindunationalistiske kredse som en illustration af den historiske modsætning mellem den første moghul Babar, hvis general opførte Babri-moskéen, og Rāma, der symboliserer den hinduistiske frihedshelt og hinduernes kampvilje. I den maskuline hindunationalisme fremstår Rāma således som en krigerisk og kampvillig repræsentant for hindukulturen, der illustrerer styrken og kampviljen i det moderne hindunationalistiske opgør med det, der opfattes som muslimernes, briternes og den sekulære indiske stats konsekutive undertrykkelse af hindunationen.

\section{Afslutning}

På samme måde som 'hinduisme' kan ses som en overordnet identificerbar størrelse, der gennem historien manifesterer sig $i$ et mylder af forskellige og til tider indbyrdes modstridende former, er historien om Rāma historisk set på samme tid een og mange. I den henseende illustrerer Rāmāyanas gang gennem indisk kulturhistorie selve dynamikken i forholdet mellem tradition og nytolkning i den hinduistiske kultursfære. De forskellige versioner af historien om Rāma og de forskellige tolkninger af den viser os, hvordan hinduismen forefindes i historien som en mangeartet og vildtvoksende tradition, igennem hvilken særlige symboler og historier løber som en rød tråd. De forskellige udformninger og tolkninger af Rāmāyana vidner desuden om, at vi her har at gøre med en tradition, der i sin udvikling har en langt mere ubunden karakter end de kristne og islamiske traditioner, som umiddelbart udgør vores referencegrundlag.

Det er tydeligt, at de historiske omstændigheder, der former karakteren af nutidens politiske brug af Rāma-skikkelsen, er determineret af elementer, der er kommet til Indien og "hindukulturen" udefra. Nutidens politiske brug af Rāma-skikkelsen er ikke bare 
en reaktion på århundreder med henholdsvis islamisk, britisk og en moderne sekulær statsmagts herredømme, men er også et politisk udtryk, der formes i forbindelse med en tilpasset demokratisk diskurs i et forsøg på at opnå politisk magt i henhold til demokratiske spilleregler. Med dette bliver det klart, at den moderne fremstilling af Rāmāyana formuleres inden for et paradigme, der er væsensforskellig fra det klassiske hinduistiske og således grundlæggende set selv repræsenterer en signifikant omformning af traditionen, til trods for dens fremstilling af sig selv som det modsatte. Den hindunationalistiske bevægelses brug af Rāma-skikkelsen illustrerer den komplicerede hermeneutiske situation i det moderne Indien, hvor gamle traditioner af inderne selv tolkes i et perspektiv, der er determineret af den kulturelle og materielle indflydelse fra Vesten i løbet af de sidste 200 år, som både ideologisk og rent praktisk ligger til grund for den moderne indiske stat. Den hindunationalistiske tolkning af Rāma er af form radikalt ny, idet den forudsætter britiske/europæiske ideer og forestillinger om f.eks. den nationale stat og eksistensen af en distinkt og homogen indisk hindukultur, der står i modsætning til andre indiske kulturer som f.eks. de indiske muslimers.

Til trods for dette illustrerer den moderne hindunationalistiske omdefinering af Rāma-skikkelsen samtidig den indiske traditions evne til at tilpasse og omtolke ældre traditioner, som vi har set det eksemplificeret ved de tidlige vaisnavistiske teologers redigering af det oprindelige Rāma-epos. 'Hinduismen' lever videre, for evigt værende "same, same, but different" - som inderne ynder at sige det, når man prøver at få noget klargjort.

\author{
Litteratur \\ BROCKINGTON, J.L. \\ 1984 Righteous Rāma, Oxford. \\ Fosse, L.M. \\ 1997 The Crux of Chronology in Sanskrit Literature, Oslo. \\ HALBFASS, W. \\ 1990 India and Europe, Delhi.
}

\author{
Summary \\ The article "Rāma: Hero, God and Political Symbol" outlines three different ways in which \\ the Rama-figure has been used in Indian history. As a basis, hermeneutical problems related \\ to the critical interpretation of the Rāmāyana are briefly discussed, and the main story of the \\ epic is outlined. \\ In the core parts of the Rāmāyana epic, Rāma can still be recognised as representing the \\ ethos of the warrior-class (ksatriya-varna). The Räma of this historical phase, approximately \\ covering the era between 400 B.C. and the Gupta era (320-500 A.D.), incarnates the dharma \\ of the ksatriya; which implies protection of the just, combat against the powers of chaos, and \\ the maintaining of the norms and the social divisions of society. When the classical Rāmā- \\ yana finds its basic form during the Gupta period, under the hands of Vaisnavite Brahmins,
}


Rāma is extolled as being an incarnation of the supreme god Visnu. As such, Rāma is God, having incarnated on earth to save mankind from evil and the universe from the powers of chaos. Brahminical notions of purity are now considered essential to the Rama-figure, with the effect that the conclusion of the original story has to be rewritten so that Räma does not take his abducted - and thus defiled - wife Sit à back after she has been liberated from the evil rāksasa Rāvana. The ksatrìya-Rāma has thus been replaced with a vaisnava-Rāma, a Rāma incarnating a different set of values.

As a parallel to this historical development, the article proceeds to outline how, during the last twenty years, Rāma has become a symbol of a new Hindu-nationalistic consciousness. In this context, Rāma is imagined as a warrior ready to fight for the assertion of "hinduness" (hindutva), in opposition to what is considered a century's old suppression carried out by Muslim rulers, the British Raj and the independent, secular Indian state. Political campaigns and the conflict around the Babri-masjid in Ayodhya, are highlighted in order to show how Rāma, through the stratagems of the Hindu nationalistic movement, has recently emerged as a symbol of an aggressive Hindu consciousness. The article stresses that the main presuppositions for the Hindu nationalistic use of Ràma are to be found in the political culture of modern India, which takes its outset in forms of organisation and concepts of political thought imported by the British. There is thus nothing essentially and eternally "Indian" about the present Hindu nationalism.

Finally, the article notes that the very fact that an ancient Indian symbol in the Hindu nationalistic context is revitalised and transformed to fit the circumstances of the present, reflects the inherent power of what we generally call "Hinduism" (a modern term originally coined by European scholars). As was the case when the original warrior-hero Rāma in the Gupta era was made into an incarnation of the supreme God, due to the mode of the religious sentiments of the time and the interest of certain classes, Rama has lately become a political symbol, due to the mode of the political sentiments in the India of the present and the interests of certain classes. Again, the complex blend of change and continuity, so characteristic of "Hinduism", leaps to mind.

Rasmus Reinvang Forskningsassistent, mag.art Skandinavisk Institut Universitetet i Gdansk Polen 